\title{
PENGARUH PENERAPAN MEDIA PEMBELAJARAN MACROMEDIA FLASH BERBASIS PROBLEM SOLVING UNTUK MENINGKATKAN HASIL BELAJAR MAHASISWA PADA MATA KULIAH PROTEKSI SISTEM TENAGA LISTRIK
}

\author{
Anggi Tandya Aisya Yori $^{1}$, Purwandari ${ }^{2}$, Sulistyaning Kartikawati ${ }^{3}$ \\ ${ }^{1,3}$ Pendidikan Teknik Elektro, Universitas PGRI Madiun \\ Madiun, 63118, Indonesia \\ ${ }^{2}$ Pendidikan Fisika, FKIP, Universitas PGRI Madiun \\ Madiun, 63118, Indonesia \\ Email:anggi.tandya@gmail.com ${ }^{1}$; \\ sulistyaningk@gmail.com ${ }^{3}$
}

\begin{abstract}
Penelitian ini bertujuan untuk mengetahui pengaruh penerapan media pembelajaran macromedia flash berbasis problem solving terhadap hasil belajar mahasiswa pada mata kuliah Proteksi Sistem Tenaga Listrik. Dalam pembelajaran mata kuliah Proteksi Sistem Tenaga Listrik kurang adanya kolaborasi penggunaan media dan metode pembelajaran yang efisien, membuat mahasiswa kurang aktif dalam pembelajaran serta minat belajar mahasiswa menjadi kurang sehingga hasil belajar mahasiswa menjadi rendah.

Penelitian ini berbentuk penelitian kuantitatif. Sampel yang digunakan satu kelas, diambil menggunakan teknik sampling jenuh dengan kelas sebelum perlakuan (pretest) diajar dengan mentode konvensional/ceramah dan kelas sesudah perlakuan (posttest) diajar dengan media pembelajaran macromedia flash berbasis problem solving. Teknik pengumpulan data menggunakan metode tes dan metode dokumentasi untuk data hasil belajar mahasiswa. Teknik analisis data menggunakan uji t.

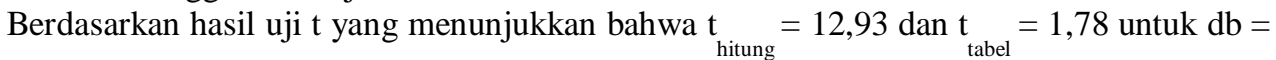
12 dan taraf signifikansi 5\%, $\mathrm{t}_{\text {hitung }}>\mathrm{t}_{\text {tabel }}$, sehingga hipotesis penelitian terbukti atau diterima. Simpulan pada penelitian ini adalah ada pengaruh dari penerapan media pembelajaran macromedia flash berbasis problem solving untuk meningkatkan hasil belajar mahasiswa pada mata kuliah Proteksi Sistem Tenaga Listrik.
\end{abstract}

Kata Kunci : Macromedia flash, Problem Solving, Hasil Belajar Mahasiswa

\section{Pendahuluan}

Proses belajar mengajar adalah proses komunikasi. Komunikasi dalam pembelajaran sering tidak seiring sehingga komunikasi dalam pembelajaran menjadi tidak efektif yang akan menyebabkan peserta didik tidak ada gairah untuk mengikuti pembelajaran. Kolaborasi pembelajaran yang baik ialah antara adanya media pembelajaran dan metode pembelajaran yang dapat membantu komunikasi pembelajaran menjadi baik serta pencapaian hasil dalam tujuan pembelajaran tercapai.

Salah satunya yang terjadi pada mata kuliah Proteksi Sistem Tenaga Listrik yang kurang adanya kolaborasi antara media pembelajaran dan metode pembelajaran. Mata kuliah Proteksi Sistem Tenaga Listrik merupakan salah satu mata kuliah yang diajarkan pada Program Studi Pendidikan Teknik Elektro Fakultas Keguruan dan Ilmu Pendidikan Universitas PGRI Madiun.

Berdasarkan pengamatan peneliti mata kuliah ini merupakan salah satu mata kuliah yang dianggap sulit untuk dipahami karena materi yang bermacam-macam dari proteksi pembangkit, transmisi, distribusi hingga instalasi pemanfaatan. Selain materi yang bermacammacam salah satu faktor lain adalah kurangnya media pembelajaran yang ada di Program 
Studi Pendidikan Teknik Elektro untuk mata kuliah Proteksi Sitem Tenaga Listrik serta pendekatan pembelajaran yang konvensional/ceramah.

Dari permasalahan yang ada, minat belajar mahasiswa pada mata kuliah ini menjadi kurang sehingga hasil belajar mahasiswa menjadi rendah di bawah Kriteria Ketuntasan Minimal (KKM) yaitu 75. Selain itu pembelajaran yang dilaksanakan membuat peserta didik menjadi bosan karena kurang adanya media pembelajaran yang komunikatif. Media pembelajaran merupakan salah satu sarana untuk meningkatkan kegiatan proses belajar mengajar.

Media pembelajaran adalah segala jenis sarana pengajaran yang digunakan sebagai perantara dalam proses belajar mengajar guna meningkatkan keefektivitas pencapaian tujuan pendidikan. Menurut (Suryani \& Agung, 2012: 155), beberapa manfaat media pembelajaran antara lain: 1) Proses pembelajaran menjadi lebih jelas dan menarik, 2) Efisiensi daalam waktu dan tenaga, 3) Meningkatkan kualitas hasil belajar mahasiswa, 4) Media dapat menumbuhkan sikap positif peserta didik terhadap materi dan proses belajar ${ }^{[3]}$.

Media pembelajaran yang populer saat ini adalah media pembelajaran yang menggunakan komputer sebagai pengendali media tersebut. Salah satunya yaitu media macromedia flash. macromedia flash dirasa cocok sebagai media pembelajaran yang dapat diterapkan pada mata kuliah Proteksi Sistem Tenaga Listrik. Macromedia flash salah satu program software yang mampu menyajikan pesan audio visual yang terdiri dari gambar, text, animasi bergerak sederhana serta efek-efek lainnya secara jelas kepada peserta didik dengan berbagai gambar animasi sehingga peserta didik lebih tertarik dalam pembelajaran, lebih memahami materi yang disampaikan pendidik, serta dapat membawa kesegaran baru bagi pengalaman belajar peserta didik.

Kemudahan yang ada pada macromedia flash sangat mendukung dalam penerapannya sebagai media pembelajaran. Macromedia flash merupakan perangkat lunak yang dapat digunakan untuk membuat sebuah animasi. Astuti dalam jurnal Utama, NP (2012: 53) mengungkapkan bahwa "Animasi adalah susunan objek yang diatur sedemikian rupa sehingga menghasilkan suatu gerakan yang mampu menarik setiap orang untuk melihantnya"[7]. Agar menghasilkan animasi yang menarik sesuai dengan tujuan penelitian maka media pembelajaran macromedia flash harus dirancang dengan baik. Maka penerapan pembelajaran menggunakan macromedia flash diharapkan dapat meningkat hasil belajar mahasiswa pada mata kuliah Proteksi Sistem Tenaga Listrik.

Metode problem solving/pemecahan masalah merupakan suatu metode mengajar yang mana peserta didik diberi soal-soal, lalu diminta pemecahannya. Tujuan dari model pemecahan masalah yaitu, untuk menanamkan kepada peserta didik bagaimana cara berfikir sistematis dan logis dalam mengatasi suatu masalah-masalah dihadapi. Hal ini akan tumbuh jika terjadi pola pembelajaran yang interaktif yang lebih menekankan komunikasi banyak arah menciptakan peserta didik sebagai variabel (Adrian dalam jurnal Muhson, A, 2007: 2) ${ }^{[2]}$.

Metode problem solving (metode pemecahan masalah) bukan hanya sekedar metode mengajar tetapi juga merupakan suatu metode berpikir, sebab dalam metode pemecahan masalah dapat menggunakan metode-metode lainnya untuk mencari data untuk dapat menarik suatu kesimpulan (Suryani, N \& Agung L, 2012: 58) ${ }^{[3]}$. Metode pemecahan masalah cocok untuk jenjang perguruan tinggi dengan tingkat permasalahan yang sesuai.

Maka peneliti mengimplementasikan pembelajaran berbasis problem solving atau yang sering disebut dengan Pemecahan Masalah pada mata kuliah Proteksi Sistem Tenaga Listrik guna membantu mahasiswa mengembangkan kemampuan pemecahan masalah baik masalah pribadi maupun masalah kelompok untuk dipecahkan sendiri ataupun secara bersama-sama 
serta mengembangkan kemampuan berfikir yang aktif serta menumbuhkan kegiatan peserta didik yang optimal.

Dengan penerapan media pembelajaran macromedia flash berbasis problem solving dirasa mahasiswa lebih interaktif dalam pembelajaran mata kuliah Proteksi Sistem Tenaga Listrik. Pembelajaran menggunakan macromedia flash dapat menciptakan suasana kelas yang aktif, peserta didik dapat lebih memahami materi secara mendalam dan dapat berulang-ulang mempelajari materi yang disajikan dalam bentuk macromedia flash. Tidak kalah pentingnya problem solving/pemecahan masalah dapat mengembangkan pikiran mahasiswa serta dapat mengidentifikasi masalah, mencari solusi, serta dapat mengevaluasi kembali masalah yang dikemukakan dalam materi Proteksi Sistem Tenaga Listrik secara pribadi maupun secara kelompok. Maka dengan adanya media pembelajaran macromedia flash berbasis problem solving di harapkan hasil belajar mahasiswa pada mata kuliah Proteksi Sistem Tenaga Listrik dapat meningkat.

Penelitian ini bertujuan untuk mengetahui pengaruh penerapan media pembelajaran macromedia flash berbasis problem solving terhadap hasil belajar mahasiswa pada mata kuliah Proteksi Sistem Tenaga Listrik

\section{Metode Penelitian}

Penelitian ini dilakukan di Program Studi Pendidikan Teknik Elektro Fakultas Keguruan Dan Ilmu Pendidikan Universitas PGRI Madiun tahun pelajaran 2016/2017. Pelaksanaan penelitian ini dilakukan secara bertahap dan sesuai dengan tahapan-tahapan penelitian yang telah disusun. Adapun tahap-tahap pelaksanaannya sebagai berikut:

a. Tahap persiapan, meliputi: pengajuan judul tesis, pembuatan proposal, pembuatan instrumen, perijinan penelitian,, konsultasi instrumen penelitian, dan validasi instrumen.

b. Tahap penelitian, yaitu semua kegiatan yang dilaksanakan di tempat penelitian, meliputi: uji instrumen penelitian dan pengambilan data yang disesuaikan dengan alokasi waktu penyampaian materi relay.

c. Tahap penyelesaian, meliputi: pengolahan data dan penyusunan laporan tesis

Berdasarkan masalah dan tujuan yang ada penelitian ini dilaksanakan dengan menerapkan metode penelitian eksperimen dengan desain penelitian One Group Pretest-Posttest Design (Sugiyono, 2016: 74-75) ${ }^{[6]}$. Hasil penelitian menegaskan bagaimana pengaruh antara variabelvariabel yang akan diteliti.

Pada penelitian ini populasi yang diteliti adalah mahasiswa semester VI Program Studi Pendidikan Teknik Elektro Fakultas Keguruan Dan Ilmu Pendidikan Universitas PGRI Madiun tahun 2016/2017 sejumlah satu kelas. dengan kelas sebelum perlakuan (pretest) diajar dengan metode konvensional/ceramah dan kelas sesudah perlakuan (posttest) diajar dengan media pembelajaran macromedia flash berbasis problem solving. Teknik pengumpulan data menggunakan metode tes kognitif untuk hasil belajar mahasiswa dan metode dokumentasi diperoleh pada saat pembelajaran.

Uji validitas instrumen pada tes hasil belajar kognitif berbentuk uraian dilakukan untuk mengetahui apakah alat evaluasi soal hasil belajar kognitif itu layak digunakan. Hasil soal kognitif uji coba kemudian dihitung validitas, reliabilitas, daya beda soal, tingkat kesukaran. 
Teknik analisis data pada penelitian ini terdiri dari uji prasyarat dan uji hipotesis. Pada uji prasyarat meliputi uji normalitas menggunakan uji Liliefors dan uji homogenitas. Menggunakan uji F. Pada uji hipotesis data penelitian menggunakan uji t. Dalam proses analisis data menggunakan bantuan program pengolah angka microscoft office excel.

\section{Hasil Penelitian dan Pembahasan}

Berdasarkan hasil uji normalitas didapatkan kesimpulan bahwa data yang diperoleh terdistribusi normal. Kriteria kenormalan: jika $\mathrm{L}_{\text {maks }} \leq \mathrm{L}_{\text {tabel }}$ maka data berdistribusi normal. Diketahui sebelum perlakuan (pretest) nilai $\mathrm{L}_{\text {maks }}=0,199$ dengan taraf signifikan $\propto=0,05$ dan daerah kritik pada uji ini $\mathrm{DK}=\left\{\mathrm{LlL}>\mathrm{L}_{0.05 ; 13-1}\right\}$ dari tabel distribusi Liliefors $\mathrm{L}_{\text {tabel }}=0,242$. nilai $\mathrm{L}_{\text {maks }} 0,199<\mathrm{L}_{\text {tabel }} 0,234$ maka Ho diterima, sampel nilai sebelum perlakuan (pretest) berdistribusi normal. Sedangkan sesudah perlakuan (posttest) diketahui nilai $\mathrm{L}_{\text {maks }} 0,202$ dengan taraf signifikan $\propto=0,05$ dan daerah kritik pada uji ini adalah $\mathrm{DK}=\left\{\mathrm{LIL}>\mathrm{L}_{0.05 ; 13-1}\right\}$ dari tabel distribusi Liliefors $\mathrm{L}_{\text {tabel}}=0,242$. Uji normalitas sesudah perlakuan (pretest) dapat diketahui nilai $\mathrm{L}_{\text {maks }} 0,202<\mathrm{L}_{\text {tabel }} 0,234$ maka Ho diterima, sampel nilai sesudah perlakuan berdistribusi normal ${ }^{[5]}$.

Tabel 1 Uji Normalitas Hasil Belajar Pretest dan Posttest

\begin{tabular}{cccc}
\hline Kelompok data & $\mathrm{L}_{\text {maks }}$ & Daerah Kritis & Status \\
\hline Pretest & 0,199 & 0,234 & Normal \\
\hline Posttest & 0,202 & 0,234 & Normal \\
\hline
\end{tabular}

Uji homogenitas didapatkan kesimpulan bahwa data yang diperoleh varian datanya homogen. Kriteria penilaian uji $\mathrm{F}_{\text {hitung }} \leq \mathrm{F}_{\text {tabel }}$, maka Ho diterima. Pengujian dilakukan dengan taraf signifikan $\propto=0,05$ dan daerah kritik pada uji ini adalah $\mathrm{F}_{\text {tabel }}\left(\alpha, v 1_{13-1}, v 2_{13-1}\right)$ hasil uji homogenitas menunjukkan hasil bahwa $\mathrm{F}_{\text {hitung }}=1,60, \mathrm{~F}_{\text {tabel }}=2,69 \mathrm{~F}_{\text {hitung }} \leq \mathrm{F}_{\text {tabel }}$. Berarti varians data sebelum perlakuan pretest dan varians data sesudah perlakuan posttest adalah homogen ${ }^{[4]}$.

Tabel 2. Uji Homogenitas Data.

\begin{tabular}{cccc}
\hline $\mathrm{F}_{\text {hitung }}$ & $\mathrm{F}_{\text {tabel }}$ & Kriteria & Simpulan \\
\hline 1,60 & 2,69 & $F_{\text {hitung }} \leq F_{\text {tabel }}$ & $H_{o}$ diterima \\
\hline
\end{tabular}

Uji Hipotesis pada penelitian ini menggunakan Uji t. kriteria pengujian Jika $t_{\text {hitung }}<t_{\text {tabel }}$ maka Ho diterima/Ha ditolak dan jika $t_{\text {hitung }}>t_{\text {tabel }}$ maka Ho ditolak/Ha diterima. Taraf signifikan $5 \%$ dengan $\mathrm{dk}=\left(\mathrm{n}-1^{)^{[1]}}\right.$. Hasil uji hipotesis disajikan pada tabel 3 .

\begin{tabular}{cccc}
\multicolumn{2}{l}{ Tabel 3 Uji Hipotesis } & & \\
\hline $\mathrm{t}_{\text {hitung }}$ & $\mathrm{t}_{\text {tabel }}$ & Kriteria & Simpulan \\
& & & \\
\hline 12,93 & 1,78 & $\mathrm{t}_{\text {hitung }}>\mathrm{t}_{\text {tabel }}$ & Ha diterima
\end{tabular}

Berdasarkan tabel 3 Uji hipotesis diperoleh $t_{\text {hitung }}=12,93$ dan $t_{\text {tabel }}=1,78$ Karena $t_{\text {hitung }}>t_{\text {tabel }}$. maka $\mathrm{H}_{\mathrm{a}}$ diterima. Jadi, dapat disimpulkan bahwa ada pengaruh penerapan media 
pembelajaran macromedia flash berbasis problem solving untuk meningkatkan hasil belajar mahasiswa pada mata kuliah Proteksi Sistem Tenaga Listrik. Hal ini terbukti pada hasil belajar mahasiswa mata kuliah Proteksi Sistem Tenaga Listrik materi Relay setelah belajar menggunakan media pembelajaran macromedia flash berbasis problem solving lebih tinggi dibandingkan sebelum perlakuan, yaitu saat mahasiswa belajar dengan metode konvensional/ceramah dan tanya jawab serta tanpa adanya media pembelajaran.

Hasil Penelitian nilai sebelum perlakuan (pretest) rata-rata 66,15 dan nilai setelah perlakuan (posttest) rata-rata 80,35, dalam hal ini menunjukkan ketercapaian keberhasilan dalam penelitian ini dari segi kognitif dapat dilihat ada peningkatan nilai hasil belajar antara sebelum perlakuan (pretest) dan setelah perlakuan (posttest). Ketercapaian peningkatan hasil belajar pada sesudah perlakuan (posttest) karena adanya sarana penunjang penerapan media pembelajaran macromedia flash yang berbasis problem solving. Sementara pembelajaran sebelum adanya perlakuan (pretest) tidak menggunakan media pembelajaran dan metode pembelajarannya konvensional/ ceramah. Bisa dilihat perbedaan hasil belajar nilai rata-rata antara ke 2 kelompok sebelum perlakuan (pretest) dan setelah perlakuan (posttest) yang nilai hasil belajarnya lebih tinggi disebabkan karena penerapan media pembelajaran serta metode pembelajaran yang membuat mahasiswa semakin aktif dan interaktif saat pembelajaran.

Setelah perlakuan (Posttest) yang menerapkan media pembelajaran sebagai sarana penunjang pembelajaran dapat menarik perhatian mahasiswa sehingga dapat menumbuhkan motivasi belajar dan dengan adanya media pembelajaran bahan materi ajar akan lebih jelas sehingga dosen lebih mudah menjelaskan dan mahasiswa dapat memahami materi yang disampaikan dengan mudah. Sehingga terdapat peningkatan hasil belajar mahasiswa pada mata kuliah Proteksi Sistem Tenaga Listrik. Dibandingkan dengan pembelajaran yang belum menerapkan media pembelajaran yangmana hanya menerapkan metode ceramah serta tanya jawab. Dari hal tersebut di atas mahasiswa tidak bisa termotivasi dan aktif dalam mengikuti pembelajaran, yang ada hanya kebosanan dalam belajar metode pembelajaran seperti ini tidak memberikan kesempatan pada mahasiswa untuk belajar sesuai dengan gaya belajarnya sendiri dan cenderung menunggu informasi-informasi materi yang disampaikan oleh dosen. Hal ini juga ditandai dengan perhitungan uji t dalam uji hipotesis yang telah dijelaskan di atas.

Sarana penunjang media pembelajaran sterategi metode pembelajaran juga sangat berpengaruh untuk pembelajaran yang aktif dan efektif. Problem solving merupakan salah satu metode pemecahan masalah, dimana metode ini dapat meningkatkan aktifitas pembelajaran mahasiswa, menantang kemampuan mahasiswa serta memberikan kepuasan untuk menemukan pengetahuan baru bagi mahasiswa dan dapat mengembangkan kemampuan mahasiswa untuk berfikir kritis dalam memecahkan masalah baik secara individu maupun kelompok pada mata kuliah Proteksi Sistem Tenaga Listrik.

Berdasarkan pembahasan di atas sudah dapat dilihat proses pembelajaran secara konvensional membuat peserta didik cenderung pasif dan tidak dapat menumbuhkan motivasi belajar pada mahasiswa sehingga berpengaruh pada perolehan hasil belajar mahasiswa yang kurang optimal. Lain halnya pembelajaran menggunakan penerapan media pembelajaran macromedia flash berbasis problem solving yang dapat menumbuhkan motivasi belajar dan mengembangkan pikiran mahasiswa dalam memecahkan masalah sehingga terdapat peningkatan hasil belajar.

Berdasarkan kesimpulan di atas dapat diketahui ada pengaruh penerapan media pembelajaran macromedia flash berbasis problem solving untuk meningkatkan hasil belajar mahasiswa pada mata kuliah Proteksi Sistem Tenaga Listrik. 


\section{Kesimpulan dan Saran}

Berdasarkan hasil analisis uji hipotesis dengan uji $\mathrm{t}$ menunjukkan hasil yang didapat $\mathrm{t}_{\text {hitung }}=$

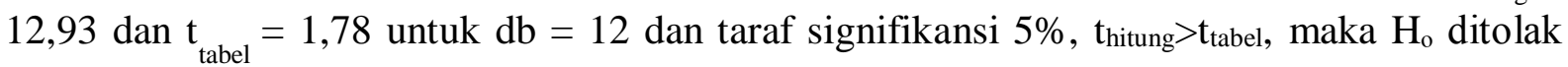
dan $\mathrm{H}_{\mathrm{a}}$ diterima. Sehingga dapat disimpulkan bahwa terdapat pengaruh penerapan media pembelajaran macromedia flash berbasis problem solving untuk meningkatkan hasil belajar mahasiswa pada mata kuliah Proteksi Sistem Tenaga Listrik.

Berdasarkan hasil penelitian yang telah diuraikan di atas, ada beberapa hal yang dapat disarankan oleh peneliti demi meningkatkan pembelajaran. Diharapkan hasil penelitian ini dapat ditindak lanjuti oleh pihak yang bersangkutan, yaitu : 1) Untuk Dosen: Hasil penelitian ini dapat dijadikan model pembelajaran alternatif bagi dosen dalam mengemas proses pembelajaran dengan menjadikan proses pembelajaran yang menyenangkan dan aktif sehingga dapat meningkatkan hasil belajar mahasiswa pada mata kuliah Proteksi Sistem Tenaga Listrik. 2) Untuk Mahasiswa: Diharapkan dalam penggunaan penerapan media pembelajaran macromedia flash berbasis problem solving untuk meningkatkan hasil belajar mahasiswa pada mata kuliah Proteksi Sistem Tenaga Listrik dapat membuat mahasiswa menjadi lebih aktif dan lebih giat dalam proses belajar dengan bekerjasama dalam kelompok untuk memecahkan masalah guna meningkatkan hasil belajar mata kuliah Proteksi Sistem Tenaga Listrik. 3) Untuk Peneliti Lain: Bagi peneliti yang berminat menggali lebih lanjut hasil penelitian ini dapat melakukannya pada tingkat dan materi yang berbeda. Diharapkan dilakukan penelitian tindak lanjut dan lebih luas lagi mengenai penerapan media pembelajaran macromedia flash berbasis problem solving untuk meningkatkan hasil belajar mahasiswa pada mata kuliah proteksi sistem tenaga listrik agar motode tersebut dapat dikembangkan dan dapat dijadikan metode pembelajaran yang lebih efektif. Menyadari akan kelemahan pada penelitian ini adalah berkaitan dengan masih sederhananya konsep pembelajaran dengan model relatif singkat dan ada beberapa mahasiswa yang kurang aktif dalam mengikuti pembelajaran.

\section{Daftra Pustaka}

[1] Arikunto, S. (2013). Prosedur Penelitian. Jakarta: PT Asdi Mahasatya

[2] Muhson, A. (2007). Penerapan Metode Problem Solving Dalam Pembelajaran Statistika Lanjut. Lumbung Pustaka Universitas Negeri Yogyakarta. (diakses13 Mei 2017)

[3] Suryani, N \& Agung, L. (2012). Strategi Belajar Mengajar. Yogyakarta: Penerbit Ombak

[4] Siregar, S. (2014). Statistika Parametrik Untuk Penelitian Kuantitatif. Jakarta: PT Bumi Aksara

[5] Sundayana, R. (2015). Statistika Penelitian Pendidikan. Bandung: Alfabeta

[6] Sugiyono. (2016). Metode Penelitian Kuantitatif, Kualitatif dan R\&D. Bandung: Alfabeta

[7] Utama, N.P \& Nilawati. (2012). Penggunaan Macromedia flash 8 Pada Pembelajaran Dimensi Tiga. Jurnal Pendidikan Matematika. 1 (1), 51-59. ejournal.unp.ac.id/students/index.php/pmat/article/download/1171/863, diunduh 25 Mei 2017) 